\title{
ANALISIS PERILAKU PENUMPANG BUS TRANSJAKARTA BLOK M-KOTA PADA MASA PANDEMI DAN PENGARUHNYA TERHADAP POLA PERJALANAN
}

\author{
Octa Rianto $^{1}$, Widodo Kushartomo² ${ }^{\text {, dan Hobyan R.S Angkat }}{ }^{3}$ \\ ${ }^{1}$ Program Studi Sarjana Teknik Sipil, Universitas Tarumanagara, Jl. Letjen S. Parman No.1 Jakarta \\ Octa.325170106@stu.untar.ac.id \\ ${ }^{2}$ Program Studi Sarjana Teknik Sipil, Universitas Tarumanagara, Jl. Letjen S. Parman No.1 Jakarta \\ Widodo@ft.untar.ac.id \\ ${ }^{3}$ Program Studi Sarjana Teknik Sipil, Universitas Tarumanagara, Jl. Letjen S. Parman No.1 Jakarta \\ hokbyanr@dtt.untar.ac.id
}

Masuk: 11-01-2021, revisi: 01-03-2021, diterima untuk diterbitkan: 02-03-2021

\begin{abstract}
ABSTRAK
The population in Jakarta continues to increase and the Covid-19 Virus had a huge impact when using Transjakarta buses, The government and the community participate in solving it. Solution is to increase self-awareness The Transjakarta busway corridor 1 is one of the most crowded corridors because there are several transit stops and routes are in urban areas, it's estimated that corridor serves 500,000 - 600,000 people or more/day, after policies on Covid-19 implemented by the Government such as restrictions the number of passengers on the busway and enforcement of the Health protocol for passengers and officers. The existence of these restrictions causes the effect of transportation travel. This research was conducted to determine the level of awareness of Transjakarta Bus passengers' behavior towards the Health protocol that is applied when carrying out activities outside the home and its effect on travel patterns, the policies realized by Transjakarta busway operator officers. The research data were obtained through questionnaire, then processed by normative and descriptive analysis methods. From the results of the analysis, it was found that passengers and officers were considered to be quite aware and good at implementing existing policies and passengers revealed that this policy affected their travel patterns.
\end{abstract}

Keywords: Covid-19 Pandemic; Transjakarta Busway; Health Protocol; Travel Pattern

\begin{abstract}
ABSTRAK
Penduduk di Jakarta terus meningkat dan Virus Covid-19 pun berdampak sekali pada saat menggunakan bus transjakarta, ada kalamya pemerintah dan masyarakat berpartisipasi dalam menyelesaikannya.Salah satu solusinya adalah meningkatkan kesadaran diri-sendiri terhadap hal tersebut.Pada Halte busway tranjakarta koridor 1 ( Blok M - Kota ) merupakan salah satu koridor yang paling ramai karena ada beberpa halte yang transit dan rutenya pun di perkotaan, perkiraan koridor 1 yang melayani 500.000 - 600.000 orang bahkan lebih per hari, Setelah kebijakankebijakan tentang Covid-19 yang diterapkan oleh Pemerintah seperti pembatasan jumlah penumpang pada busway dan pemberlakuan protokol kesehatan untuk penumpang maupun petugas. Adanya Batasan-batasan ini menyebabkan pengaruh perjalanan transportasi. Penelitian ini dilakkan untuk mengetahui tingkat kesadaran perilaku penumpang Bus Transjakarta terhadap protokol kesehatan yang diterapkan ketika melakukan kegiatan di luar rumah dan pengaruhnya terhadap pola perjalanannya, juga untuk mengetauhi kebijakan yang direalisasikan oleh petugas operator busway Transjakarta. Data penelitian didapatkan melalui kuesioner, lalu diolah dengan metode analisis normative dan deskriptif. Dari hasil analisis, didapatkan bahwa baik penumpang maupun petugas dinilai sudah cukup sadar dan baik dalam menerapkan kebijakan yang ada dan penumpang mengungkapkan dengan adanya kebijakan ini memperngaruhi pola perjalanannya.
\end{abstract}

Kata kunci: Pandemi Covid- 19 ; Busway Transjakarta ; Protokol Kesehatan ; Pola Perjalanan,

\section{PENDAHULUAN}

Pada era globalisasi ini sangat banyak hal yang mengalami modernisasi, salah satunya ialah sarana transportasi. Sarana transportasi memiliki peranan yang penting dan tidak dapat dipisahkan bagi kehidupan masyarakat. Semakin banyaknya pilihan jasa transportasi, membuat masyarakat mencari-cari pilihan mana yang paling ideal untuk dirinya sendiri. Contoh yang menjadi pilihan banyak masyarakat adalah busway Transjakarta. 
Transjakarta merupakan sistem BRT dengan jalur lintasan terpanjang di dunia $(230,9 \mathrm{~km})$, serta memiliki 243 stasiun BRT (sebelumnya disebut halte) yang tersebar dalam 13 koridor (jalur), yang awalnya beroperasi dari 05.00 - 22.00 WIB, dan kini beroperasi 24 jam di Sebagian.

Namun, pada 2 Maret 2020 ini Indonesia dikejutkan dengan kasus terkonfirmasi positif virus Covid-19 yang sudah mewabah di seluruh dunia. Terhitung sampai dengan tanggal 29 Mei 2020, Pemerintah Indonesia menyatakan keadaan darurat bencana akibat dari penyebaran virus ini yang terus meningkat dan menyebabkan penetapan kebijakan untuk melakukan tindakan Pembatasan Sosial Berskala Besar dengan sosialisasi gerakan Social Distancing. Kebijakan pembatasan ini pun berpengaruh pada banyak aspek penting tak terkecuali pada transportasi. Pembatasan ini berlaku di semua moda transportasi, baik itu di darat, laut, maupun udara di era yang bisa kita sebut New Normal ini khususnya pada transportasi umum termasuk pelayanan busway Transjakarta.

Batasan masalah dalam penelitian ini antara lain:

1. Perilaku dari penumpang yang menggunakan transportasi umum busway Transjakarta koridor 1.

2. Persepsi masyarakat terhadap regulasi dan pola pelayanan dari busway Transjakarta koridor 1 berdasarkan protokol kesehatan Covid-19.

Rumusan masalah yang akan dibahas pada penelitian ini adalah:

1. Bagaimana regulasi-regulasi yang berlaku dalam mengatur moda transportasi khususnya busway Transjakarta koridor 1 pada pemberlakuan Pembatasan Sosial Berskala Besar dalam masa pandemi ini?

2. Bagaimana timbal balik yang dilakukan PT.Transportasi Jakarta selaku operator dalam menerapkan regulasiregulasi yang berlaku untuk petugas maupun penumpang busway Transjakarta?

3. Bagaiman persepsi dari masyarakat selaku penumpang dalam menggunakan moda transportasi busway Transjakarta koridor 1 mengenai regulasi-regulasi yang diberlakukan dalam halte maupun bus?

4. Apakah kebijakan - kebijakan Pembatasan Sosial Berskala Besar yang berlaku pada masa pandemi wabah virus Covid-19 dalam busway Transjakarta berpengaruh terhadap perjalanan transportasi yang dilakukan masyarakat?

Tujuan dari penelitian ini adalah:

1 Mengetahui bagaimana regulasi-regulasi yang berlaku dalam mengatur moda transportasi khususnya busway Transjakarta koridor 1 pada pemberlakuan Pembatasan Sosial Berskala Besar dalam masa pandemi ini?

2. Mengetahui bagaimana timbal balik yang dilakukan PT. Transportasi Jakarta selaku operator dalam menerapkan regulasi-regulasi yang berlaku untuk petugas maupun penumpang busway Transjakarta?

3. Mengetahui bagaiman persepsi dari masyarakat selaku penumpang dalam menggunakan moda transportasi busway Transjakarta koridor 1 mengenai regulasi-regulasi yang diberlakukan dalam halte maupun bus?

4. Mengetahui apakah kebijakan - kebijakan Pembatasan Sosial Berskala Besar yang berlaku pada masa pandemi wabah virus Covid-19 dalam busway Transjakarta berpengaruh terhadap perjalanan transportasi yang dilakukan masyarakat?

\section{Transportasi}

Transportasi adalah memindahkan barang (commodity of goods) dan penumpang dari suatu tempat ke tempat lain, sehingga pengangkut menghasilkan jasa angkutan atau produksi jasa bagi masyarakat yang membutuhkan untukpemindahan atau pengiriman barang-barangnya menurut (Soegijatna Tjakranegara, 1996). Menurut (Baerwald, Huber, dan Keefer, 1976) penumpang yang baik adalah penumpang yang taat pada Peraturan yang ditetapkan oleh Pemerintah.

Moda transportasi publik di antaranya bus kota dan kereta api, kereta cepat (metro/subway/bawah tanah, dsb). Angkutan umum antar kota didominasi oleh organisasi-organisasi penerbangan, bus antar-kota, kereta api, dan kereta antar-kota. Jaringan kereta berkecepatan tinggi sedang dikembangkan di banyak belahan dunia. Sistem transportasi umum berjalan di sepanjang rute tetap dengan titik pemberhentian dengan jadwal yang telah diatur sebelumnya. Taksi berbagi menawarkan layanan berdasarkan-permintaan di banyak bagian dunia, dan beberapa layanan akan menunggu sampai kendaraan penuh sebelum taksi tersebut berangkat.

\section{PT. Transjakarta}

Busway Transjakarta adalah sistem transportasi Bus Rapid Transit (BRT) pertama di Asia Tenggara dan Selatan, yang beroperasi sejak tahun 2004 di Jakarta, Indonesia. Sistem ini didesain berdasarkan sistem TransMilenio yang sukses di Bogota, Kolombia. Transjakarta dirancang sebagai moda transportasi massal pendukung aktivitas ibu kota yang sangat padat. Transjakarta merupakan sistem BRT dengan jalur lintasan terpanjang di dunia (230,9 km), serta 
memiliki 243 stasiun BRT (sebelumnya disebut halte) yang tersebar dalam 13 koridor (jalur), yang awalnya beroperasi dari 05.00 - 22.00 WIB, dan kini beroperasi 24 jam di sebagian koridornya.

Transjakarta memiliki sistem BRT terpanjang di dunia pada tahun 2017, dengan 13 koridor utama dan 10 rute lintas koridor. Tiga koridor lagi dijadwalkan dimulai pada tahun 2014 atau 2015 dan sebagian akan meningkat sedangkan koridor yang ada berada pada tingkat dasar. Selain itu ada 18 rute yang terus melewati akhir busway eksklusif ke kota-kota di sekitar Jakarta dan menggunakan bus khusus yang memungkinkan untuk naik di tingkat dasar atau platform stasiun Transjakarta.

\section{Pandemi wabah virus corona (COVID-19) di Indonesia}

Pada 30 Januari 2020, WHO mendeklarasikan status wabah 2019-nCoV sebagai Darurat Kesehatan Global untuk keenam kalinya sejak Wabah flu babi 2009. Ini diakibatkan karena risiko penyebaran global, terutama ke negaranegara berpenghasilan rendah dan menengah tanpa sistem kesehatan yang kuat yang mampu melakukan pengawasan setelah kemungkinan penularan dari manusia ke manusia terkonfirmasi.

Kasus pertama COVID-19 dikonfirmasi di Indonesia pada 2 Maret 2020, dengan 2 warga Kota Depok, Provinsi Jawa Barat dinyatakan positif mengidap virus penyebab penyakit tersebut. Pada 15 Maret, Indonesia mengumumkan 117 kasus yang terkonfirmasi dan Presiden Joko Widodo menyerukan kepada penduduk Indonesia untuk melakukan langkah-langkah pembatasan sosial, sementara beberapa pemimpin daerah di Jakarta, Banten dan Jawa Barat sudah menutup sekolah dan tempat-tempat umum. Keesokan harinya, Joko Widodo menyampaikan bahwa ia tidak akan melakukan karantina wilayah atau penguncian (lockdown). Pada 27 Maret, Dedy Yon Supriyono, Wali kota Tegal, Provinsi Jawa Tengah mengumumkan bahwa kota yang dipimpinnya akan menerapkan tindakan penguncian lokal, menutup beberapa titik akses ke dan dari kota, dan menjadi lokasi pertama yang melakukannya di Indonesia.

\section{Kebijakan operasional angkutan umum pada masa pandemi}

Gugus Tugas sebagai badan yang menangani soal kebijakan yang berlaku pada masa pandemi ini menerbitkan SE Gugus Tugas No.7 Tahun 2020 setelah masa berlaku SE Gugus Tugas No. 4 Tahun 2020 habus. SE Gugus Tugas No. 7 Tahun 2020 berisi tentang Kriteria dan Persyaratan Perjalanan Orang dalam Masa Adaptasi Kebiasaan Baru Menuju Masyarakat Produktif dan Aman Corona Virus Disease 2019 (Covid-19) yang merupakan salah satu bentuk dari arah kebijakan menuju era new normal demi membangkitkan atau memulihkan roda perekonomian negeri. Di saat yang bersamaan diterbitkan Permenhub No. 41 Tahun 2020 tentang Perubahan atas Peraturan Menteri Perhubungan No. 18 Tahun 2020 tentang Pengendalian Transportasi dalam Rangka Pencegahan Penyebaran Corona Virus Disease 2019 (Covid-19), yang seluruhnya secara garis besar memberikan pelonggaran kapasitas angkutan terhadap masing-masing angkutan.

Masyarakat yang ingin menggunakan busway Transjakarta diwajibkan untuk memenuhi beberapa persyaratan yang perlu untuk diterapkan. Beberapa di antaranya ialah dengan memenuhi aturan utama dari protokol kesehatan yaitu memakai masker, mencuci tangan, dan menjaga jarak, sangat disarankan untuk menggunakan face shield, pakaian lengan panjang atau jaket. PT. Transjkarta dalam hal ini memfasilitasi tempat cuci tangan beserta sabunnya untuk mencuci, disediakan juga hand sanitizer. Pihak petugas juga berkewajiban melengkapi protokol kesehatan sebagai frontliner yang bertugas, melakukan pengcekan suhu tubuh kepada penumpang yang akan masuk ke area stasiun, pemberlakuan maksimal kapasitas pada tiap pemberangkatannya, di dalam bus dilarang untuk berbicara atau melenfon, memberikan marka-marka untuk menjaga jarak, dan membersihkan rangkaian Busway saat mengakhiri perjalanan.

\section{METODE PENELITIAN}

Untuk memastikan penelitian berjalan dengan lancar dan mencapai tujuan akhirnya secara tepat, perlu untuk menjabarkan tahapan penelitian. Adapun tahapan dalam penelitian ini adalah seperti terlampir pada Gambar 1 . 


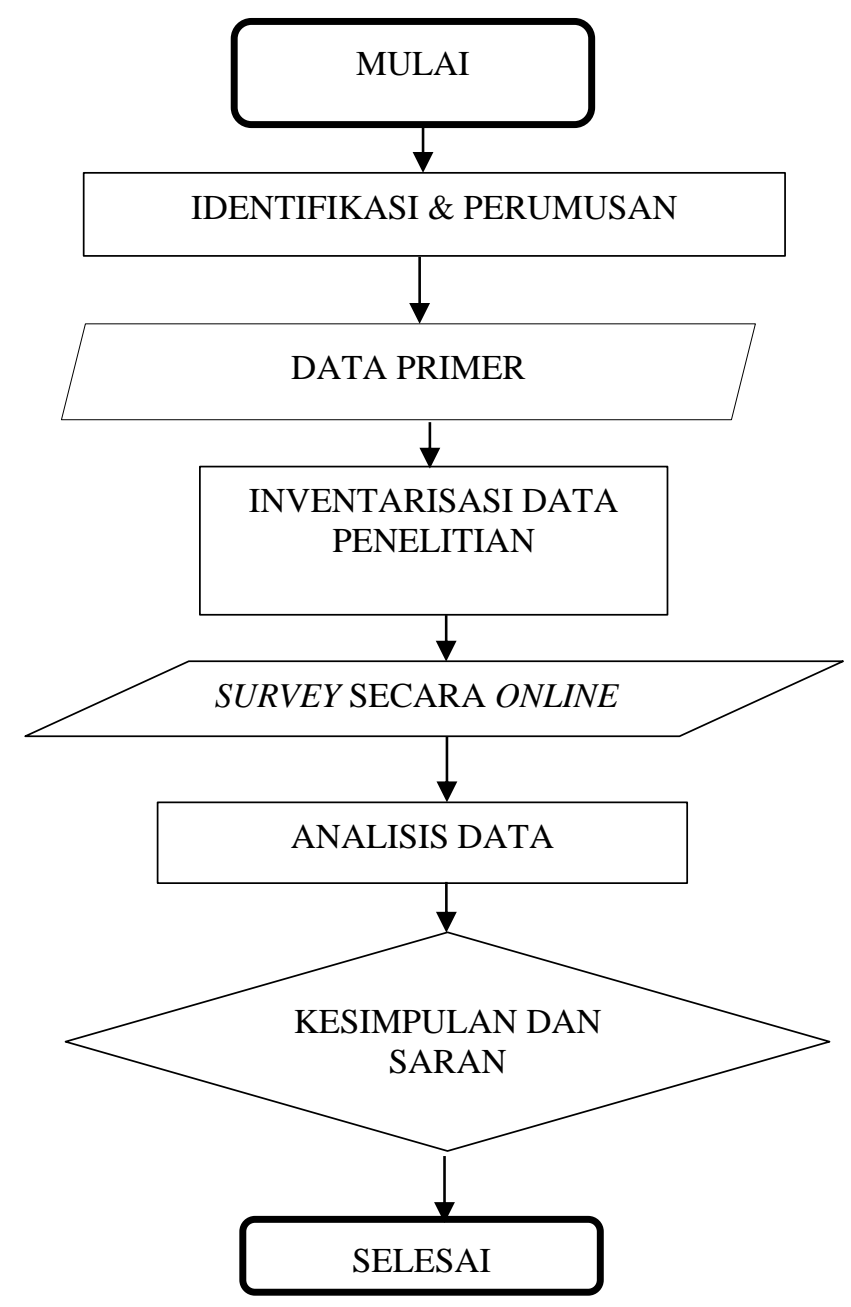

Gambar 1. Diagram alir tahapan penelitian

\section{Jenis penelitian}

Penelitian yang dilakukan dikhususkan pada jalur Koridor 1 Blok M -Kota busway Transjakarta. Data didapatkan melalui survey online, disebarluaskan dengan link google form. Survey ini ditujukan pada konsumen sebagai penumpang transjakarta mengenai perilaku penumpang dan operator dalam menerapkan protokol kesehatan dan kebijakan lain yang berlaku di masa pandemi Covid-19.

\section{Responden atau objek studi}

Responden yang dijadikan objek studi dalam analisis penulis ialah konsumen sebagai penumpang busway transjakarta yang menggunakan jalur Koridor 1 Blok M - Kota busway Transjakarta. Semua responden yang akan diwawancara dengan survey online diharapkan bisa memberikan jawaban yang jujur sesuai dengan kenyataan yang ada di lapangan, sehingga hasil penelitian ini memiliki validitas yang tinggi dan dapat dipertanggungjawabkan keaslian datanya. Untuk para responden yang merupakan penumpang dibedakan dari segi jenis kelamin, usia, pendapatan per bulan, pekerjaan yang dilakukan, frekuensi penggunaan busway Transjakarta, persepsi terhadap penerapan protokol kesehatan ataupun kebijakan lainnya yang diterapkan oleh operator moda jasa transportasi PT. Transjakarta menurut para penumpang, dan pengaruhnya terhadap pola perjalanan penumpang.

\section{Metode pengumpulan data}

Dalam mengumpulkan data, metode yang digunakan adalah menggunakan kuesioner. Kuesioner merupakan sejumlah pertanyaan atau pernyataan tertulis tentang data faktual atau opini yang berkaitan dengan diri responden, yangdianggap fakta atau kebenaran yang diketahui dan perlu dijawab oleh responden (Sutoyo, 2009).Kuesioner disebarluaskan dengan cara online (tidak dilakukan secara langsung) untuk mengetahui dan mengidentifikasi bagaimana pendapat dari sudut pandang penumpang terhadap dirinya sendiri dan operator petugas yang bertugas di 
area halte atau di dalam bus. Hal lain yang dituliskan dan dilakukan analisis adaalah persepsi penumpang mengenai penerapan kebijakan protokol kesehatan yang seharusnya dilakukan oleh operator petugas PT. Transjakarta. Wawancara ini diharapkan dapat dijawab oleh penumpang yang terpercaya, guna mendapatkan hasil data penelitian yang valid.

\section{Metode analisis data}

Menurut (Bell, Raiffa, dan Tversky, 1998) analisis deskriptif, yakni mendeskripsikan data yang diperoleh dari hasil pengamatan, wawancara, dokumen dan catatan lapangan, kemudian dianalisa yang dituangkan kedalam bentuk tesis. dari desain penelitian yang telah dirancang melalui kuesioner, maka didapatkan persepsi perilaku masing-masing dari penumpang khususnya juga dari sisi pihak PT. Transjakarta. Masing-masing paparan persepsi yang didapat dilakukan analisis melalui penumpang terhadap kebijakan-kebijakan dan peraturan yang sudah diberlakukan mengenai protokol kesehatan, apakah sudah sesuai dengan praktik di lapangan. Melalui persepsi pendapat yang sudah dipaparkan dari penerapan kebijakan dari penumpang itu sendiri maupun petugas yang bertugas dapat dibuat penilaian secara subjektif seberapa terealisasi kebijakan-kebijakan yang diberlakukan dari badan WHO dan diadaptasi kembali sesuai di negara Indonesia oleh Menhub, Kemenkes dan Pemda. Setelah melakukan analisis terhadap persepsi pendapat dengan faktual yang terjadi melalui Analisis Normatif tersebut, dengan Analisis Deksriptif dibuat kesimpulan dengan gambaran berdasarkan paparan dari sudut pandang responden mengenai kebijakan yang diberlakukan ini. Dari data-data tiap pendapat persepsi dan saran serta masukan yang telah dipaparkan dilakukan analisis kembali agar didapatkan hasil yang ideal bagi semua pihak dan di evaluasi. Hasil evaluasi yang didapatkan akan mempresentasikan hasil publik.

\section{HASIL DAN PEMBAHASAN}

\section{Data responden}

Data yang didapatkan secara Daring (Dalam jaringan) atau survey online menggunakan Google Form direncanakan untuk 200 responden, namu hasil responden yang didapat ada sebanyak 171 responden dengan hasil yang beragam. Berikut adalah data dari Responden, yang didapatkan adalah Karakteristik responden yang terdapat pada tabel 1 .

Tabel 1. Karakteristik responden

\begin{tabular}{|c|c|c|}
\hline Karakteristik & Jumlah (orang) & Presentase \\
\hline \multicolumn{3}{|l|}{ Janis Kelamin } \\
\hline Laki-laki & 124 & $72,51 \%$ \\
\hline Perempuan & 47 & $27,49 \%$ \\
\hline \multicolumn{3}{|l|}{ Usia } \\
\hline$<20$ tahun & 22 & $12,87 \%$ \\
\hline b) 21-30 tahun & 104 & $60,82 \%$ \\
\hline c) $31-40$ tahun & 45 & $26,32 \%$ \\
\hline \multicolumn{3}{|l|}{ Wilayah tempat tinggal } \\
\hline Pinangsia & 12 & $7,02 \%$ \\
\hline Mangga Besar & 20 & $11,70 \%$ \\
\hline Kebon Kelapa & 14 & $8,19 \%$ \\
\hline Gambir & 16 & $9,36 \%$ \\
\hline Kebon Sirih & 20 & $11,70 \%$ \\
\hline Gondangdia & 19 & $11,11 \%$ \\
\hline Menteng & 4 & $2,34 \%$ \\
\hline Setiabudi & 5 & $2,92 \%$ \\
\hline Karet & 8 & $4,68 \%$ \\
\hline Karet Semanggi & 8 & $4,68 \%$ \\
\hline Gelora & 1 & $0,58 \%$ \\
\hline Senayan & 13 & $7,60 \%$ \\
\hline
\end{tabular}


Tabel 1. Karakteristik responden ( Lanjutan )

\begin{tabular}{lcc}
\hline Selong & 18 & $10,53 \%$ \\
\hline Lainnya & 13 & $7,60 \%$ \\
\hline Pendidikan Terakhir & 70 & $40,94 \%$ \\
\hline a) SD/SLTP/SLTA & 12 & $7,02 \%$ \\
\hline b) Diploma (D1/D2/D3/ D4) & 76 & $44,44 \%$ \\
\hline c) S1 & 13 & $7,60 \%$ \\
\hline d) Magister S2 & & $30,95 \%$ \\
\hline Pekerjaan & 65 & $16,19 \%$ \\
\hline a) PNS/Pegawai BUMN & 34 & $4,29 \%$ \\
\hline c ) Profesional/Swasta & 9 & $20,48 \%$ \\
\hline f) Ibu Rumah & 43 & $28,10 \%$ \\
\hline Pelajar/Mahasiswa & 59 & $38,01 \%$ \\
\hline Lainnya & & $5,85 \%$ \\
\hline Penghasilan per bulan & 65 & $21,05 \%$ \\
\hline < Rp. 1.000.000 & 10 & $10,53 \%$ \\
\hline Rp. 1.000.000 - Rp. 2.000.000 & 36 & 18 \\
\hline Rp. 2.000.000 - Rp. 3.000.000 & & \\
\hline Rp. 3.000.00 - Rp. 4.000.000 & $19 \%$ \\
\hline
\end{tabular}

Berikut adalah Protokol Kesehatan yang digunakan oleh penumpang terdapat pada Tabel 2.

Tabel 2. Protokol Kesehatan yang digunakan/dilakukan oleh penumpang

\begin{tabular}{cc}
\hline Penumpang & Persentase \\
\hline Sterilisasi tempat duduk & $50,29 \%$ \\
\hline menggunakan masker-face shield-sarung tangan & $53,80 \%$ \\
\hline Sterilisasi pada diri sendiri & $50,29 \%$ \\
\hline memakai masker-face shield- sarung tangan & $49,12 \%$ \\
\hline Jaga jarak & $49,71 \%$ \\
\hline Sterilisasi diri setelah melakukan aktivitas & $45,61 \%$ \\
\hline Menggunakan handphone atau smartphone selama perjalanan & $100,00 \%$ \\
\hline Saat turun dari bus melakukan aktivitas jaga jarak saat tiba di halte akhir tujuan & $98,25 \%$ \\
\hline Melakukan pensterilan diri seperti mengganti masker dan penyemprotan handsanitizer & $88,89 \%$ \\
\hline
\end{tabular}

Fasilitas yang disediakan oleh Operator terdapat pada Tabel 3.

Tabel 3. Fasilitas yang disediakan oleh operator

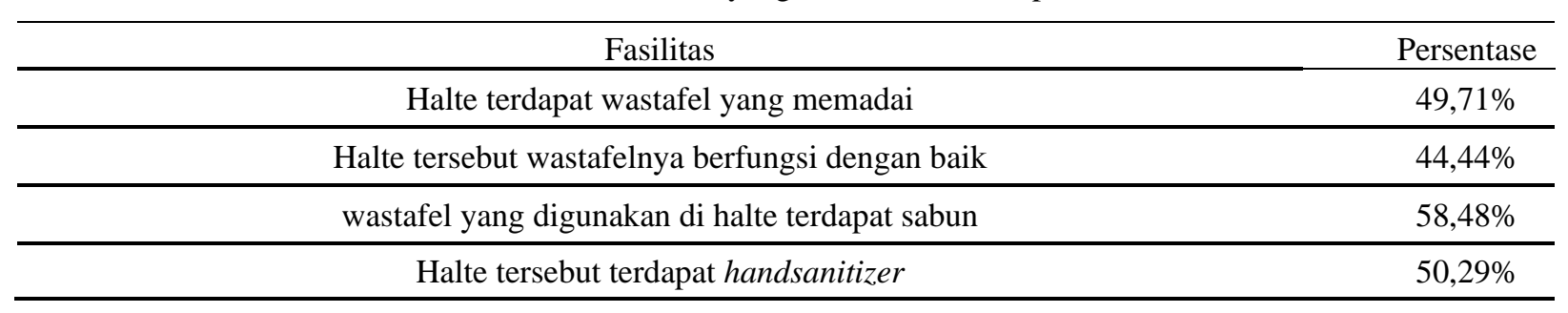


Tabel 3. Fasilitas yang disediakan oleh operator ( Lanjutan )

\begin{tabular}{cc}
\hline Fasilitas & Persentase \\
\hline Jumlah handsanitizer-nya mencukupi & $44,44 \%$ \\
\hline covid-19 dari banner-flyer-pengumuman suara atau video di dalam halte & $58,48 \%$ \\
\hline Tempat duduknya sudah diatur sesuai dengan kebijakan Kemenkes dan Kemenhub & $90,06 \%$ \\
\hline erdapat fasilitas hand sanitizer & $90,76 \%$ \\
\hline Mengatasi bahaya covid-19 dari pengumuman suara atau video di dalam halte & $98,83 \%$ \\
\hline Halte tujuan terdapat fasilitas wastafel dan handsaniter & $98,25 \%$ \\
\hline Adanya tindakan sterilisasi seperti penyemprotan disinfektan dan pembersihan lainnya pada \\
bus yang anda naikki & $88,30 \%$ \\
\hline
\end{tabular}

mendapatkan himbauan untuk tetap melaksanakan protokol kesehatan dalam mengatasi

bahaya covid-19 dari banner-flyer-pengumuman suara atau video di dalam halte

Berikut adalah Tanggung jawab Petugas terhadap peraturan yang diterapkan oleh Pemerintah yang terdapat pada tabel 4.

Tabel 4. Tanggung jawab petugas terhadap peraturan yang diterapkan oleh Pemerintah

\begin{tabular}{cc}
\hline Petugas & Persentase \\
\hline Petugas melakukan pemeriksaan tubuh & $53,80 \%$ \\
\hline petugas menegur penumpang yang tidak mematuhi aturan protokol kesehatan & $48,54 \%$ \\
\hline petugas melakukan pengarahan pergerakan penumpang & $55,56 \%$ \\
\hline petugas melakukan tugasnya seperti menganjurkan penumpang untuk saling menjaga jarak & $48,54 \%$ \\
\hline Petugasnya mengarahkan penumpang untuk duduk sesuai dengan tempat yang telah disediakan & \multirow{2}{*}{$97,66 \%$}
\end{tabular}

Rata- rata

$60,82 \%$

\section{Analisis protokol kesehatan pada penumpang busway Transjakarta Blok M- Kota}

Berdasarkan data yang didapatkan, penumpang dari rumah ke halte semuanya adalah memakai masker dan sebanyak 66 penumpang membawa hand senitizer, sisanya memakai protokol kesehatan tambahan, ternyata mayoritas masyarakat memakai kain masker sebesar 71 penumpang, lalu Kebanyakan masyarakat hanya membawa 1 buah masker atau tidak ada membawa masker cadangan, hanya beberapa masyarakat yang membawa masker cadangan,

Pada perjalanan penumpang dari rumah ke halte yang menggunakan transportasi online, kendaraan pribadi sebanyak 50 pesen lebih yang menggunakan hand sanitizer pada tempat duduk sebelum ia duduk, menggunakan masker-face shield-sarung tangan dan Sterilisasi pada diri sendiri dan semua penumpang menggunakan masker-face shield pada saat di perjalanan menuju halte Ketika Saat berada di Halte, sebanyak 49,12\% penumpang masih ada keswaspadaan diri , sebanyak 49,17\% yang berjaga jarak, sterilisasi diri setelah melakukan aktivitas sebesar $45,61 \%$, sebanyak 49,71\% mengatakan Halte terdapat wastafel yang tidak memadai, sebesar lebih dari 50 persen mengatakan halte tersebut wastafelnya tidak/kurang berfungsi dengan baik, Sebanyak 58,48\% mengatakan wastafel yang digunakan di 
halte terdapat sabun sudah memadai, sebanyak 44,44\% mengatakan Halte tersebut terdapat hand-sanitizer, dan sebanyak 58,48\% mangatakan terdapat pengumuman suara atau video di dalam halte tentang Covid-19, Sebanyak $53,80 \%$ penumpang mengatakan Petugas melakukan pemeriksaan tubuh sisanya tidak. Sebanyak $48,54 \%$ mengatakan petugas yang menegur penumpang yang tidak mematuhi aturan protokol kesehatan, sebanyak $55,56 \%$ mengatakan petugas melakukan pengarahan pergerakan penumpang dan lebih dari 80 persen penumpang saat menggunakan gadget saat di dalalm bus,

Saat perjalanan Halte menuju halte lainya , semua penumpang mnggunakan masker- face shield dan sarung tangan, sebanyak 98,83\% yang duduk di tempat uang telah disediakan oleh pihak halte, semua penumpang pun saling menjaga jarak saat berdiri. Sebanyak $90,06 \%$ penumpang yang mengatakan tempat duduknya sudah diatur sesuai dengan kebijakan Kemenkes dan Kemenhub, Petugas-petugas yang mengarahkan penumpang untuk duduk sesuai dengan tempat yang telah disediakan sebanyak 97,66\% mengatakan ada melakukan, Sebanyak 90,76\% mengatakan terdapat hand sanitizer, Semuanya mengatakan menggunakan handphone atau smartphone selama perjalanan, dan sebanyak 98,33\% mengatakan adanya pengumuman suara atau video di dalam halte,

Saat berada di Halte tujuan, sebanyak 98,25\% mengatakan saaat turun dari bus ada melakukan aktivitas jaga jarak di halte tujuan, sebanyak 88,98 \% responden mengatakan ada melakukan pensterilan diri-sendiri seperti menggantikan masker dan menyemprotan hand-sanitizer, sebanyak 98,25\% responden mengatakan Halte tujuannya terdapat fasilitas wastafel dan hand-sanitizer, sebanyak 88,30\% mengatakan adanya tindakan strerilisasi seperti penyemprotan disinfektan dan pembersihan lainnya pada bus yang dinaikki dan $97,666 \%$ mengatakan ada himbauan untuk tetap melaksanakan protokol kesehatan dalam mengatasi bahaya covid-19 dari banner flyer, pengumuman suara atau video di dalam halte

Keamanan, Kenyamanan, dan Pengaruh Terhadap Penggunaan Transjakarta yang sangat merasa aman dan terlindungi saat dari rumah sampai halte hanya 26,32\% sedangkan yang merasa sangat tidak nyaman sebanyak $30,41 \%$, yang sangat merasa aman dan terlindungi saat di halte keberangkatan hanya $24,56 \%$. Sedangkan yang merasa sangat tidak nyaman sebanyak 19,30\%, yang sangat Merasa aman dan terlindungi saat melakukan perjalanan di dalam bus sebanyak $18,71 \%$ sedangkan yang merasa sangat tidak nyaman sebanyak $24,56 \%$, yang merasa sangat aman dan terlindungi saat berada di halte akhir tujuan sebanyak 28,07\% sedangkan yang merasa sangat tidak nyaman sebanyak 23,39\%, sebanyak 24,56 \% sangat setuju dengan anjuran Pemerintah mengenai Work From Home (WFH), sedangkann yang sangat tidak setuju sebesar $26,32 \%$,

\section{Analisis pola perjalanan}

Dalam analisis pola perjalanan penumpang busway Transjakarta koridor 1, penelitian ini melakukan pembatasan cakupan aspek perubahan pada pola perjalanan hanya berdasarkan pada kebijakan - kebijakan yang ditetapakan oleh pemerintah pusat khususnya yang berpengaruh baik langsung maupun tidak langsung, Pengaruh kebijakan tersebut dapat dilihat pada pembatasan yang diterapkan pada pembatasan terhadap kapasitas penumpang pada bus, pembatasan jadwal jam operasional busway Transjakarta serta kebijakan mengenai Work From Home (WFH), Kebijakan Work From Home sendiri dapat berbentuk pembatasan hari kerja pada para pekerja dalam seminggu, pembatasan jam kerja dalam satu hari, serta pembatasan jumlah pekerja di tempat kerja dalam satu waktu,

Analisis pola perjalanan ditinjau berdasarkan aspek keamanan dan kenyamanan penggunaan busway Transjakarta dan juga kebijakan pemerintah yang dianjurkan khususnya mengenai Work From Home.

\section{Keamanan dan kenyamanan}

Melalui paparan sudut pandang penumpang busway Transjakarta merasa sudah cukup aman dan nyaman untuk melakukan perjalanan transportasi dengan busway Transjakarta khususnya pada lintas Blok M - Kota, namun tidak dapat dihindarkan ada beberapa responden yang menyatakan tetap merasa kurang bahkan tidak aman dan nyaman dalam melakukan perjalanan transportasi, Berdasarkan tanggapan responden didapat $\geq 80 \%$ penumpang busway Transjakarta merasa dengan adanya kebijakan - kebijakan yang ada pada masa pandemi ini berpengaruh terhadap perjalanan transportasinya, beberapa di antaranya menyebutkan bahwa jadi lebih waspada dan hati-hati lagi, serta melakukan banyak persiapan untuk melakukan suatu perjalanan,

Jika dilihat dari sudut pandang penumpang busway Transjakarta selaku responden pada penelitian ini, dengan tingginya tingkat keamanan dan kenyamanan yang dirasakan, dapat dikatakan operator yaitu PT, Transjakarta sudah cukup baik dalam menerapkan protokol kesehatan dan menyediakan fasilitas-fasilitas yang dianjurkan apabila ingin menggunakan transportasi umum busway Transjakarta dengan mengaplikasikan sesuai dari kebijakan Kemenkes dan Permenhub yang diadaptasi dari World Health Organization (WHO) sehingga bisa didapatkan penumpang memiliki rasa aman dan nyaman ketika menggunakan busway Transjakarta pada jalur lintas Blok M - Kota khususnya pada masa pandemi. 


\section{Kebijakan pemerintahan}

Yang menjadi fokus tinjauan pada analisis bagian ini adalah dari sisi protokol, dimana pengaruh itu dapat dilihat dari apa yang telah dirasakan setelah adanya kebijakan ini, dan juga dari sisi kebijakan soal anjuran pemerintah mengenai Work From Home (WFH), yang dimana berdasarkan hasil persepsi responden merupakan keinginan personal dari responden itu sendiri,

Dengan berpengaruhnya kebijakan - kebijakan yang ada pada masa pandemi ini terhadap perjalanan transportasi penumpang busway Transjakarta, didapat sebanyak 108 responden memilih untuk melakukan pembatasan terhadap kegiatan luar, 22 responden memilih tetap melakukan kegiatan luar dengan merubah waktu keberangkatan yang digunakan dari yang biasanya, dan sebanyak 41 responden memilih untuk membatalkan segala kegiatan luar,

Dari sudut pandang penumpang busway Transjakarta selaku responden pada penelitian ini, dapat dikatakan PT, Transjakarta sudah cukup baik menerapkan protokol kesehatan yang dianjurkan apabila ingin menggunakan transportasi umum busway Transjakarta dengan mengaplikasikan sesuai dari kebijakan Kemenkes dan Permenhub yang diadaptasi dari World Health Organization (WHO), Dari sudut pandang penumpang busway Transjakarta juga menyatakan penumpang yang menggunakan busway Transjakarta dinilai sudah sadar terhadap kesehatannya masing - masing dan juga lingkungan sekitarnya, dengan taat mengaplikasikan protokol kesehatan yang dianjurkan untuk melakukan perjalanan transportasi.

\section{KESIMPULAN DAN SARAN}

\section{Kesimpulan}

Berdasarkan hasil dan pembahasan penelitian ini dapat diketahui 4 hal yaitu karakteristik individu, karakteristik perjalanan, tingkat kewaspadaan penumpang dan fasilitas protokol kesehatan yang diediakan halte menurut pengguna busway transjakarta dan khususnya pada koridor 1 (Blok M - Kota). Berdasarkan hasil analisis ini dapat diambil beberapa kesimpulan:

1. Karakteristik individu pengguna busway transjakarta baik umum maupun yang khususnya melalui halte harmoni didominasi oleh jenis kelamin laki-laki, berdasarkan usia baik umum maupun yang khususnya melalui Halte Harmoni didominasi pada usia 21 - 30 tahun, berdasarkan tempat tinggal umumnya didominasi pada daerah Provinsi DKI Jakarta, berdasarkan pendidikan baik umum maupun yang khususnya melalui Halte Harmoni didominasi oleh pendidikan S1, berdasarkan pekerjaan baik umum maupun yang khususnya melalui Halte Harmoni didominasi oleh profesional/swasta, dan berdasarkan penghasilan bulanan baik umum maupun yang khususnya melalui Halte Harmoni didominasi oleh penghasilan sebesar Rp. 2.000.001,00 -Rp. 3.000.000,00,

2. Karakteristik perjalanan pengguna busway transjakarta berdasarkan maksud perjalanannya baik umum maupun yang khususnya melalui Halte Harmoni didominasi dengan maksud untuk Berkerja/Pulang, berdasarkan frekuensi penggunaan busway transjakarta umumnya didominasi dengan frekuensi sesuai kebutuhan, berdasarkan halte keberangkatannya didominasi dari Halte Harmoni dengan persentase sebesar 17,54\% berdasarkan stasiun tujuannya didominasi oleh Halte Harmoni dengan persentase sebesar 12,54, berdasarkan moda menuju/dari stasiun baik umum maupun yang khususnya melalui Halte Harmoni didominasi dengan moda angkutan online,

3. Mayoritas penumpang pada Perjalanan halte Tosari, Bundaran HI dan Karet Sudirman merasa nyaman dan aman pada saat menaiki halte tersebut akan tetapi pada halte harmoni,Blok-M, Kota dan Bundaran Senayan merasa tidak nyaman dan aman, Mayoritasnya yang berada halte tersebut adalah pekerja di perusahaan swasta dan PNS

4. Fasilitas yang kurang memadai kebanyakan pada halte Masjid Agung dan Olimo, kurangnya handsanitizer, wastafel yang kurang memadai dll, Mayoritasnya yang berada halte tersebut adalah laki-laki yang berusia sekitar 30-40 tahun

5. Mayoritas penumpang yang dulunya menaiki busway sekarang menjadi jarang atau tidak menaiki karena kebijakan pemerintah dan pandemi covid-19 tapi masih ada beberapa masyarakat merasa terpaksa menggunakan busway sebagai moda perjalanan karena harus bekerja,

6. Mayoritas merasa tidak aman dan nyaman saat Pemerintah membuat peraturan tentang melimitkan mejadi 13 koridor pada saat PSBB.

\section{Saran}

Berikut ini adalah beberapa saran yang penulis berikan untuk arah perkembangan selanjutnya:

1. Sebaiknya fasilitas protokol Kesehatan diperbanyak dan ditingkatkan kualitas protokol kesehatan seperti saat mencuci tangan, membuka kerannya menggunakan sensor atau menggunakan kaki, dan lainnya 
2. Pemerintah harus memperketat lagi pada saat ada pelanggaran protokol Kesehatan seperti denda yang tinggi atau tidak perlu melayani secara gratis pada saat terkena covid-19,

3. Saling bertorelansi antar sesama, Seperti masyarakat harus lebih berpikir bagaiamana Pemerintah menangani covid-19 dan dampak masyarakat terhadap covid-19,

4. Peraturan Pemerintah harus dipertimbangkan konskuensinya pada saat terealisasi di lapangan, seperti jumlah koridornya dibatasi menjadi 12 koridor malahan membuat masyarakat menjadi lebih banyak menggunakan transportasi karena takut tidak keburu,

5. Survey kueosioner dilakukan secara online sehingga tingkat validasinya berkurang karena target penumpang tidak terjangkau, jadi sangat disarankan survey secara offline

\section{DAFTAR PUSTAKA}

Baerwald, J E , Huber, M J, LE. "Urban Travel Characteristics Baewald.” Transportation and Traffic Engineering Handbook (1965).

David E.Bell, Howard Raiffa \& Amos Tversky. Descriptive, normative, and prescriptive interactions in decision making. In: Decision making: Descriptive, normative, and prescriptive interactions. Cambridge University Press, 1998.

S, Tjakranegara. Hukum Pengangkutan Barang dan Penumpang. jakarta: Rineka Cipta, 1996.

Sutoyo, A. Pemahaman Individu, Observasi, Checklist Interview, Kuisioner dan Sosiometri. Yogyakarta:: Pustaka Belajar, 2009.

Surat Edaran Gugus Tugas No. 7 Tahun 2020 tentang Kriteria dan Persyaratan Perjalanan Orang dalam Masa Adaptasi Kebiasaan Baru Menuju Masyarakat Produktif dan Aman Corona Virus Disease 2019 (Covid19)Surat Edaran Menteri Perhubungan No. 11 Tahun 2020 